\title{
CORRELATION OF SALT SENSITIVITY, PLASMA RENIN ACTIVITY AND ALDOSTERONE IN HYPERTENSIVE PATIENTS
}

\author{
Nebojsa Tasic ${ }^{1}$, Danijela Tasic ${ }^{1}$, Dalibor Dragisic ${ }^{2}$, Miroslav Mitrovic ${ }^{3}$ \\ ${ }^{1}$ Cardiovascular Institute „Dedinje“, Belgrade, Serbia \\ ${ }^{2}$ Univeristy Hospital Center „Dr Dragisa Misovic - Dedinje“, Belgrade, Serbia \\ ${ }^{3}$ Hypertension, infarction and stroke prevention association - HISPA, Belgrade, Serbia
}

\author{
POVEZANOST SO SENZITIVNOSTI, PLAZMA RENINSKE AKTIVNOSTI \\ I NIVOA ALDOSTERONA KOD PACIJENATA SA HIPERTENZIJOM \\ Nebojša Tasić ${ }^{1}$, Danijela Tasić ${ }^{1}$, Dalibor Dragišić ${ }^{2}$, Miroslav Mitrović ${ }^{3}$ \\ ${ }^{1}$ Institut za kardiovaskularne bolesti Dedinje“, Beograd, Srbija \\ ${ }^{2}$ Kliničko-bolnički centar „Dr Dragisa Mišović - Dedinje“, Beograd, Srbija \\ ${ }^{3}$ Udruženje centara za hipertenziju, prevenciju infarkta i šloga - HISPA, Beograd, Srbija
}

Received / Primljen: 10. 07. 2017.

Accepted / Prihvaćen: 11. 07. 2017.

\begin{abstract}
Plasma-renin values vary in normotensive and hypertensive populations. Some studies consider renin to be a key factor in the aetiology of hypertension, but other studies note that renin is an important factor in cardiovascular homeostasis and functions more as a growth factor than as a pressor hormone. The aim of this study was to assess the PRA and aldosterone values under different salt intake regimes in patients with essential hypertension. The study group consisted of 50 untreated patients (27 women and 23 men; aver-

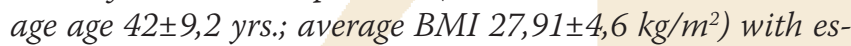
sential hypertension. All patients were put on a high-sodium diet (200 mmol NaCl per day) for one week after a week on a low-sodium diet (20 mmol $\mathrm{NaCl}$ per day). Sodium sensitivity (SS) was defined as a $10-\mathrm{mmHg}$ increase in the mean blood pressure at the end of the high-vs. the low-sodium diet. The SS group consisted of 26 patients, and the sodiuminsensitive group consisted of 24 patients. The PRA and aldosterone levels were determined in 12 patients. PRA values in the SS group during rest were significantly lower compared with the salt-resistant group during all regimes of salt intake ( $F=10,56, p=0,0012)$. Salt loading in SS patients causes a significant decrease in PRA (in rest and effort) values in comparison to values during a low salt intake regime (rest: $t=4,49, p<0,001$; effort: $t=3,45, p<0,01)$. The PRA values in the salt-resistant group did not vary significantly under the different salt intake regimes. The aldosterone values followed the pattern of the PRA values. It is necessary to distinguish investigations on salt intake effects based on incidence and value of blood pressure and investigations on salt restriction's effects on of blood pressure levels (i.e., non-pharmacological hypertension therapy).
\end{abstract}

Keywords: Hypertension, plasma renin activity, aldosterone, salt sensitivity

\section{SAŽETAK}

Vrednosti renina $u$ plazmi variraju $u$ normotenzivnoj $i$ hipertenzivnoj populaciji. Neka istraživanja ukazuju da renin ima značajnu ulogu u etiologiji hipertenzije dok druge studije ističu njegovu ulogu u kardiovaskularnoj homeostazi kao faktora rasta. Cilj studije je ispitivanje vrednosti plazma reninske aktivnosti (PRA) $i$ aldosterone tokom različitih režima unosa soli kod bolesnika sa esencijalnom hipertenzijom. U studiju je uključeno 50 nelečenih bolesnika. (27 žena

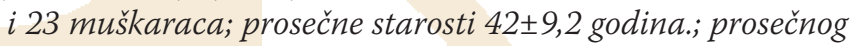
indeksa telesne težine $27,91 \pm 4,6 \mathrm{~kg} / \mathrm{m}^{2}$ ) sa esencijalnom hipertenzijom. Svi pacijenti su bili na dijeti bogatoj soli sedam dana (200 mmol NaCl dnevno) posle nedelju dana na dijeti sa niskim sadržajem soli (20 mmol $\mathrm{NaCl}$ dnevno). So-senzitivnost je definisana kao porast srednjeg krvnog pritiska za $10 \mathrm{mmHg}$ na kraju povećanog unosa soli u odnosu na period sa niskim unosom soli So-senzitivnih bolesnika je bilo 26 dok je so-rezistentih bilo 24. PRA i aldosteron su odredeni kod 12 bolesnika. Pokazano je da su vrednosti PRA u so-senzitivnoj grupi bolesnika bili statistički niže u mirovanje u poređenju sa so-rezistentnim bolesnicim tokom svih režima unosa soli. ( $F=10,56, p=0,0012)$. Takođe je pokazano da je opterećenje soli dovelo do značajnog sniženja PRA kod so-senzitivnih bolesnika (u miru i naporu) u poredenju sa PRA vrednostima tokom dijete sa niskim unosom soli (mirovanje: $t=4,49$, $p<0,001$; naport: $t=3,45, p<0,01)$. PRA vrednosti u so-rezistentnoj grupi nisu značajno varirale tokom različitih režima unosa soli. Vrednosti aldosterone su pratili obrazac PRA vrednosti. Neophodno je preciznije istražiti sve obrasce so-senzitivnosti radi bolje determinacije ne-farmakološke terapije hipertenzije kod ovih bolesnika.

Ključne reči: hipertenzija, plazma reninska aktivnost, aldosteron, so senzitivnost 


\section{INTRODUCTION}

With a decrease in extracellular volume, the binding of ATII to its receptors on vascular smooth muscle cells decreases due to previous ATII bindings to the same receptors, which leads to lower blood pressure levels. At the same time, the number of ATII receptors is increased on suprarenal glands, which causes increased aldosterone production. The overall result is sodium retention without a significant increase in blood pressure. It has been reported that the modulation of the adrenal and vascular responses to ATII is non-adequate in $30-50 \%$ of hypertensive patients, who are then considered "non-modulators".

Most patients with essential hypertension are not characterized as expected (i.e., higher perfusion pressure in juxta-glomerular cells and higher blood volume), with low, inhibited plasma-renin activity (PRA) but are instead characterized rather withby normal or even high PRA values. According to Sealey and co., this discrepancy is caused by nephron heterogeneity, with a special subgroup of ischaemic nephrons that contribute to high PRA values ${ }^{2}$.

The third model of "non-modulation" was proposed by Williams and Holenberg ${ }^{3}$. Healthy individuals modulate the response of target tissues to ATII according to their sodium intake. Decreased sodium intake is followed by an increase in aldosterone production and a decrease in vascular response. During sodium loading, the suprarenal response is decreased, and the vascular response is increased, especially in the kidney circulation, which stimulates sodium excretion from the kidney. Williams and Holenberg reported that $50 \%$ of patients with essential hypertension with normal and/or high PRA values are characterized with disorders of ATII modulation on target tissues according to sodium intake and are considered "non-modulators". Regulatory disorders characterized by fixed ATII concentrations in target tissues lead to increased aldosterone production during sodium restriction and increased blood flow in the kidney circulation during sodium loading. The confirmation of this hypothesis was achieved by the correction of abnormalities with ACE inhibitor administration.

Numerous mechanisms of pathogenesis in hypertensive patients with low PRA values have been described ${ }^{4}$. In the majority of patients, low PRA values are followed by normal (not low, as expected) aldosterone values, which are explained by increased sensitivity of the suprarenal glands to ATII. Several studies have shown low rates of cardiovascular complications in patients with essential hypertension and low PRA values ${ }^{5,6}$. Other studies have revealed that diuretic therapy is more efficient in hypertensive patients with low PRA values than in hypertensive patients with high PRA values. In the former group, diuretic therapy leads to smaller increases in PRA values, with smaller vascular responses and aldosterone production, which cause decreases in plasma volume and blood pressure ${ }^{7}$.

In "bipolar vasoconstriction-volume analysis", the vasoconstriction of the kidney's arterioles is caused by ATII actions, which are responsible for hypertension in patients with high PRA values, and increased plasma volume, which is responsible for hypertension in patients with low PRA values $_{8,9}$. It should be emphasized that most clinicians and research workers rely on PRA blood values, but the tissue concentrations might be different, and the pathogenesis of the disorder might be even more complicated.

\section{AIM OF THE STUDY}

The aim of this study was to assess PRA and aldosterone values during different regimes of salt intake in patients with essential hypertension.

\section{PATIENTS AND METHODS}

The study group consisted of 50 untreated patients (27 women and 23 men; average age $42 \pm 9,2$ yrs.; average BMI $\left.27,91 \pm 4,6 \mathrm{~kg} / \mathrm{m}^{2}\right)$ with essential hypertension. The causes of secondary hypertension were excluded with standardized endocrinological investigation, and antihypertensive therapy was stopped two weeks before the study. A finding of fixed elevated blood pressure ${ }^{3} 160 / 95 \mathrm{mmHg}$ without therapy over at least four days was considered as stable hypertension. Borderline hypertension was defined as a temporary increase in diastolic pressure ${ }^{3} 90 \mathrm{mmHg}$ during three different measurements. Hypertension was classified according to the Seventh Joint Committee for the detection, evaluation and treatment of hypertension. The study was conducted in hospital. All patients were put on a high-sodium diet (200 $\mathrm{mmol} \mathrm{NaCl}$ per day) for one week after a week on a low-sodium diet $(20 \mathrm{mmol} \mathrm{NaCl}$ per day). Sodium sensitivity was defined as a $10-\mathrm{mmHg}$ increase in mean blood pressure at the end of the high- vs. the lowsodium diet. The sodium-sensitive group consisted of 26 patients, and the sodium-insensitive group consisted of 24 patients. The electrolytes in serum and urine and blood pressure were measured on the last day of normal salt intake and on $1^{\text {st }}, 3^{\text {rd }}$ and $5^{\text {th }}$ days of the low- and high-sodium diets. All patients had normal sodium and potassium serum concentrations. Sodium intake was controlled by 24hour urine sampling, and sodium excretion between 100 and $150 \mathrm{mmol} / \mathrm{d}$ was considered satisfactory. Calcium intake was standardized and was approximately $817 \mathrm{mg}$ per day. During the 7-day low-sodium diet, sodium intake was balanced to achieve a sodium excretion of $40 \mathrm{mmol}$ per day. During the high-sodium intake, $10 \mathrm{mg}$ of salt $(\mathrm{NaCl})$ was added to each participant's normal food intake. Sodium excretion more than $200 \mathrm{mmol} /$ day was considered satisfactory during the high-sodium diet. Blood samples for aldosterone and PRA determinations were prepared according to standardized procedures. Aldosterone was measured using a Maia-Biodata radioimmunoassay with a normal range of $0.03324-0.4155 \mathrm{nmol} / \mathrm{l}$ in the lying position, with an interassay $\mathrm{CV}=8.8 \%$ and an intraassay $\mathrm{CV}=7.6 \%$. PRA was measured using a Sorin Biomedica radioimmuno- 
Table 1. Average PRA and aldosteron values (rest and effort) during different regimes of salt intake

\begin{tabular}{|c|c|c|c|c|c|c|}
\hline \multirow[t]{2}{*}{ Regime } & \multicolumn{2}{|c|}{ Normal salt intake } & \multicolumn{2}{|c|}{ Low salt intake } & \multicolumn{2}{|c|}{ High salt intake } \\
\hline & rest & effort & rest & effort & Rest & effort \\
\hline \multicolumn{7}{|l|}{ PRA } \\
\hline Salt-sensitive & $0,16 \pm 0,03$ & $0,22 \pm 0,08$ & $0,20 \pm 0,04$ & $0,26 \pm 0,05$ & $0,12 \pm 0,01$ & $0,16 \pm 0,06$ \\
\hline Salt-resistent & $0,27 \pm 0,06$ & $0,44 \pm 0,21$ & $0,21 \pm 0,07$ & $0,41 \pm 0,18$ & $0,25 \pm 0,09$ & $0,45 \pm 0,02$ \\
\hline \multicolumn{7}{|l|}{ Aldosteron } \\
\hline Salt-sensitive & $0,3 \pm 0,14$ & $0,46 \pm 0,14$ & $0,36 \pm 0,14$ & $0,58 \pm 0,29$ & $0,13 \pm 0,04$ & $0,21 \pm 0,1$ \\
\hline Salt-resistent & $0,33 \pm 0,1$ & $0,53 \pm 0,3$ & $0,31 \pm 0,08$ & $0,74 \pm 0,52$ & $0,44 \pm 0,19$ & $0,53 \pm 0,21$ \\
\hline
\end{tabular}

assay, with a normal range of $0.1542-2.159 \mathrm{nmol} / \mathrm{l} / \mathrm{h}$ in the lying position and a normal range of $1.1565-4.3947 \mathrm{nmol} / \mathrm{l} / \mathrm{h}$ in the supine position, with an interassay $\mathrm{CV}=11.5 \%$ and an intraassay $\mathrm{CV}=9.9 \%$. Blood pressure was measured daily at 8 AM (before breakfast) and at 6 PM with the same sphygmomanometer. Blood pressure value was considered the average value of two measurements on the non-dominant arm after 5 minutes of rest. The criteria for hypertension were diastolic pressure ${ }^{3} 90 \mathrm{mmHg}$, (Korotkoff phase V) and/ or systolic pressure ${ }^{3} 140 \mathrm{mmHg}$ without therapy. Patients were divided to a salt-sensitive and a salt-resistant group according to the change in mean arterial pressure during the low- and high-salt diets ( 20 vs. $200 \mathrm{mmol} /$ day). Average values of mean arterial pressure were used for the determinations of salt sensitivity. Increases of more than 10 $\mathrm{mmHg}$ in the mean arterial pressure of were considered salt sensitivity. The RMANOVA test, correlation analysis methods, and the unpaired and paired t-tests were used for statistical analyses.

\section{RESULTS}

PRA and aldosterone levels were determined in $12 \mathrm{pa}-$ tients. Two blood samples were obtained in morning hours (in rest and effort) on normal salt intake and on the $5^{\text {th }}$ days of the low- and high-salt diets. After analysing the data, we divided patients into a salt-sensitive group (with low basal PRA values) and a salt-resistant group (with high basal PRA values).

Statistical analysis revealed that PRA values in the saltsensitive group during rest were significantly lower compared with the salt-resistant group during all regimes of salt intake $(\mathrm{F}=10,56, \mathrm{p}=0,0012)$.

It was also shown that salt loading in salt-sensitive patients caused significant decreases in PRA values (in rest and effort) in comparison with values during the low-salt intake regime. (rest: $t=4,49, p<0,001$; effort: $t=3,45, p<0,01$ ). PRA values in the salt-resistant group did not vary significantly during the different regimes of salt intake (Table 1).

Aldosterone values followed the pattern of PRA values and were significantly different in the salt-sensitive group (in rest and effort) between the high- and low-salt intake regimes (rest: 3,53, $\mathrm{p}<0,01$; effort: $\mathrm{t}=2,37, \mathrm{p}<0,05$ ).
Correlation analysis of PRA and aldosterone values with calcium parameters revealed positive correlations between PRA, aldosterone and ionized calcium (PRA: $r=0,62$, $r^{2}=0,38, p=0,034$, aldosterone: $\left.r=0,51 ; r^{2}=0,26 ; p=0,041\right)$ in salt-sensitive patients during the high-salt intake regime. No significant correlations were found between these parameters during the normal and low-salt intake regimes.

A negative correlation between PRA and urinary calcium was found in the high-salt intake regime in salt-sensitive patients $\left(r=-0,41 ; r^{2}=0,17 ; p=0,049\right)$. Aldosterone was not significantly correlated with urinary calcium.

Total blood calcium was not significantly correlated with PRA and aldosterone during all three regimes. We also found negative correlations of PRA $\left(r=0,53, r^{2}=0,28\right.$, $\mathrm{p}=0,02)$ and aldosterone $\left(\mathrm{r}=-0,47, \mathrm{r}^{2}=0,22, \mathrm{p}=0,035\right)$ values with mean arterial pressure regarding salt sensitivity during the high-salt intake regime.

\section{DISSCUSION}

Kawasaki and co-workers first divided essential hypertension into salt-sensitive and salt-resistant types according to the response of blood pressure to salt loading ${ }^{10}$. Data presented in the literature showed that salt sensitivity in established essential hypertension occurs in between 30 and $60 \%$ of cases ${ }^{11}$. In borderline hypertension, salt sensitivity occurs in $29 \%$ of cases, while in the normotensive population, salt sensitivity occurs in $16-25 \%$ of cases. The prevalence of salt-sensitive hypertension depends on the defining criteria. For the definition of salt sensitivity, some authors use changes in salt intake, and others use the response of blood pressure to the ratio of the increase in volume due to sodium intake and the decrease due to diuretic administration $^{12,13}$. Different sodium intake protocols are also used (20 and $220 \mathrm{mmol} / \mathrm{d}$ or 70 and $370 \mathrm{mmol} / \mathrm{d}$ ). It is important to emphasize that changes in blood pressure in response to sodium intake follow a normal distribution curve; therefore, the division is arbitrary.

In several studies, Resnick and co-workers showed correlations between calcium metabolism disturbances, salt sensitivity, PRA and aldosterone system and calcium-regulating hormones in hypertensive patients ${ }^{14,15}$. The results of these studies showed the characteristic metabolic and 
hormonal profiles of salt-sensitive patients (low basal PRA values, higher PTH and 1,25- $(\mathrm{OH})_{2}-\mathrm{D}$ values, lower calcitonin values, low ionized calcium and higher serum magnesium values), while the salt-resistant group was characterized by reversed metabolic and hormonal profiles. The first studies that investigated the pathogenesis of hypertension explained the increase in the intracellular calcium concentration (and the increase in vascular resistance) by the primary disturbance in membrane ion transport or the actions of some circulating factors on membrane transport ${ }^{16}$. Resnick showed that PRA and calcium-regulated hormones co-ordinate the modulation of sodium's and calcium's effects on blood pressure by influencing membrane ion transport and intracellular ion concentrations. The authors stated that salt and calcium sensitivities could be partially explained by disturbances in metabolic and hormonal parameters ${ }^{17}$. Other authors confirmed the presence of low PRA values in salt-sensitive normotensive and hypertensive individu$\mathrm{als}^{18}$. with the salt-resistant group during different regimes of salt intake. Salt loading in the salt-sensitive group caused significant decreases in PRA values, both in rest and effort, in comparison with those values during low sodium intake. Aldosterone values in our study followed the pattern of PRA values during all diet regimes. We also investigated the correlations of different parameters. We found positive correlations between PRA values, aldosterone and ionized calcium and a negative correlation between PRA values and urinary calcium during the high-salt intake regime. Our study also revealed negative correlations between PRA and aldosterone values and mean arterial pressure regarding salt sensitivity during the high-salt intake regime. These results are similar to those of Resnick's group and some other authors, who found significantly low PRA values in salt-sensitive hypertensive and normotensive persons and higher PRA values in salt-resistant individuals ${ }^{19,20}$. Resnick especially emphasized that low PRA values and ionized calcium could be excellent predictors of the hypotensive effect of calcium supplementation in hypertensive patients.

Some studies have shown that salt-resistant hypertensive patients have higher PRA and aldosterone serum values in comparison with salt-sensitive persons during a low-salt intake regime ${ }^{21,22}$. Our study confirmed these findings, although we did not detect significant correlations. Significant decreases in these parameters in the salt-sensitive group during salt loading could partially explain better possibilities for the excretion of loaded sodium. Other authors did not find significant differences in basal PRA and aldosterone values in normotensive, salt-sensitive and salt-resistant hypertensive persons during different salt intake regimes ${ }^{23,24}$.

Numerous authors found negative correlations between decreased blood pressure during salt restriction and increased PRA values ${ }^{25}$. The degree of renin system reactivity could predict the response of blood pressure to salt restriction. Cappuccio administered saralasin (a competitive AII inhibitor) to hypertensive patients on the $5^{\text {th }}$ day of a low-salt intake regime. The decrease in blood pressure caused by saralasin administration was negatively correlated with the decreased blood pressure caused by sodium restriction. Patients with the most prominent decrease in blood pressure during salt restriction had the smallest decrease of blood pressure during saralasin administration, demonstrating the significance of the renin-angiotensin-aldosterone response to salt restriction. A special subgroup involves patients with heart failure, where more liberal sodium intake can achieve an adequate suppression of plasma renin levels ${ }^{26}$. Paterna et al., in a randomized clinical trial, showed that sodium restriction to $80 \mathrm{mmol} /$ day significantly increased hospitalization and mortality compared with a sodium intake of $120 \mathrm{mmol} /$ day in patients with compensated heart failure and aggressive diuretic therapy ${ }^{27}$.

\section{CONCLUSION}

It is necessary to distinguish investigations on the effects of salt intake on the incidence and values of blood pressure from investigations on salt restriction's effects on blood pressure levels (i.e., a non-pharmacological therapy for hypertension). Research on salt-sensitive parameters seeks details to quantify the already-established correlation. Different factors could play significant roles in the salt sensitivity phenomenon: i.e., higher sodium retention, abnormal supressibility of the RAAS system, abnormal responses of the sympathetic nervous system, differences in vascular reactivity and abnormality in Na-K-ATP enzymes.

\section{REFERENCES}

1. Williams GH, Dluhy RG, Lifton RP, Moore TJ, Gleason R, Williams R, Hunt SC, Hopkins PN, Hollenberg NK. Non-modulation as an intermediate phenotype in essential hypertension. Hypertension. 1992 Dec;20(6):788-96.

2. Sealey JE, Blumenfeld JD, Bell GM, Pecker MS, Sommers SC, Laragh JH. On the renal basis of essential hypertension. Nephron heterogeneity with discordant renin secretion and sodium excretion causing a hypertensive vasoconstriction-volume relationship. Kidney Int 1988;34(Supp1 25):S64-S7.

3. Gaboury CL, Simonson DC, Seely EW, Hollenberg NK, and Williams GH. Relation of pressor responsiveness to angiotensin II and insulin resistance in hypertension. J Clin Invest. Dec 1994; 94(6): 2295-2300.

4. Sahay M, and Sahay RK. Low renin hypertension. Indian J Endocrinol Metab. 2012 Sep-Oct; 16(5): 728-739.

5. Alderman MH, Madhavan S, Ooi WL, Cohen H, Sealey JE, Laragh JH. Association of the renin-sodium profile with the risk of myocardial infarction in patients with hypertension. N Engl J Med 1991;324:1098-1104.

6. Alderman $\mathrm{MH}$, Laragh JH and Sealey. JE. More about plasma renin and cardiovascular Mortality. European Heart Journal. 2011 doi:10.1093/eurheartj/ehr187. 
7. Wyndham RN, Gimenez L, Walker WG, Whelton PK, Russell RP. Influence of renin levels on the treatment of essential hypertension with thiazide diuretics. Arch Intern Med. 1987. 147(6):1021-5.

8. Laragh JH. Laragh's Lessons in Renin System Pathophysiology for Treating Hypertension and its Fatal Cardiovascular Consequences. New York: Elseivier Science Inc., 2003.

9. Laragh JH. Vasoconstriction-volume analysis for understanding and treating hypertension: the use of renin and aldosterone profiles. Am J Med 1973;55:261-274.

10. Kawasaki T., Delea C.S., Bartter F.C., Smith H. The effect of high-sodium and low-sodium intakes on blood pressure and other related variables in human subjects with idiopathic hypertension. Am J Med. 1978; 64: 193-8.

11. Weinberger MH. Salt Sensitivity of Blood Pressure in Humans. Hypertension. 1996; 27: 481-490.

12. Sullivan JM. Salt sensitivity. Definition, conception, methodology, and long-term issues. Hypertension. 1991 Jan;17(1 Suppl):I61-8.

13. B. Wedler, M. Wiersbitzki, S. Gruska, E. Wolf, and F. C. Luft. Definitions and Characteristics of Salt-sensitivity and Resistance of Blood Pressure: Should the Diagnosis Depend on Diastolic Blood Pressure? Clinical and experimental hypertension1992. 14(6): 1037-1049.

14. Resnick, L.M., Muller, F.B., Laragh, J.H. Calcium-regulation hormones in essential hypertension: relation to plasma renin activity and sodium metabolism. Ann Intern Med 1986; 105: 649-54.

15. Resnick, L.M., Nicholson J.P., Laragh J.H. Calcium metabolim in essential hypertension: relationship to altered renin system activity. Federation proceedings 1986; Vol. 45, No. 12; November: 2739-2744.

16. MacGregor G.A., Markandu N.D., Sagnella G.A., Singer D.R.J. Cappuccio F.P. Double-blind study of three sodium intakes and long-term effects of sodium restriction in essential hypertension. Lancet 1989; ii: 1244-1247.

17. Resnick, L.M. Calciotropic hormones in salt-sensitive essential hypertension: 1,25-dihydroxyvitamin D and parathyroid hypertensive factor. Journal of Hypertension 1994; Vol 12 (suppl 1): S3-S9.
18. Weinberger M.H., Miller J.Z., Luft F.C., Grim C.E., Finenberg N.S. Definitions and characteristics of sodium sensitivity and blood pressure resistance, Hypertension 1986; 8 (Suppl II):II-127-II134.

19. Ferri C. Sodium-modulating hormones and the pressor response to sodium chloride in essential arterial hypertension. Ann Med Int. 1993; Apr - Jun; 8(2): 89-94.

20. Overlack A. Divergent hemodynamic and hormonal responses to varying salt intake in normotensive subjects. Hypertension. 1993 Sep; 22(3): 331-8.

21. Pimenta E, Gaddam KK, Oparil S, Aban I, Husain S, Dell'Italia JE,Calhoun DA.Salt Intake and Hypertension Effects of Dietary Sodium Reduction on Blood Pressure in Subjects With Resistant Hypertension. Hypertension. 2009; 54: 475-481

22. Sullivan J.M., Ratts T.E. Sodium sensitivity in human subjects: hemodynamic and hormonal correlates. Hypertension 1988; 11: 717-23.

23. Draaijer P. Salt-sensitivity testing in patients with borderline hypertension: reproducibility and potential mechanisms. J Hum Hypertens. 1995; Apr; 9(4): 263-9.

24. Gerdts E. Salt sensitive essential hypertension evaluated by 24 hour ambulatory blood pressure.; Blood Press. 1994; Nov; 3(6): 375-80.

25. Schwartz GL, Bailey K, Chapman AB, et al. The role of plasma renin activity, age, and race in selecting effective initial drug therapy for hypertension. Am J Hypertens 2013; 26:957.

26. Cappuccio FP, Markandu ND, Sagnella GA, MacGregor GA. Sodium restriction lowers high blood pressure through a decreased response of the renin system--direct evidence using saralasin. J Hypertens. 1985 Jun;3(3):243-7.

27. Cody RJ, Covit AB, Schaer GL, Laragh JH, Sealey JE, Feldschuh J. Sodium and water balance in chronic congestive heart failure. J Clin Invest 1986;77:1441-1452.

28. Paterna S, Gaspare P, Fasullo S, Sarullo FM, Di Pasquale P. Normal-sodium diet compared with low-sodium diet in compensated congestive heart failure: is sodium an old enemy or a new friend? Clin Sci (Lond) 2008;114:221-230. 


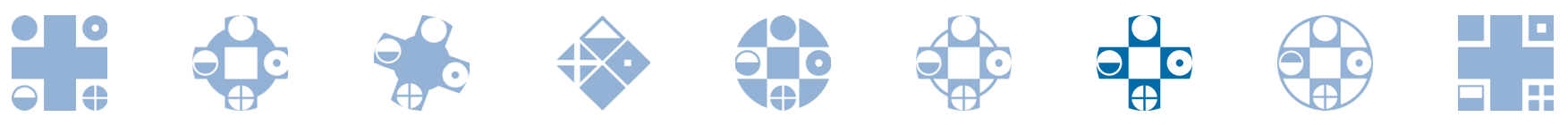

